\title{
Wat op dees (van) aarde beteken die einde van tradisionele metafisiese taal oor God? In gesprek met die Nuwe-Testamentikus Andries Gideon van Aarde oor sy verstaan van ' $n$ postsekulêre spiritualiteit
}

\begin{abstract}
Author:
Daniël P. Veldsman ${ }^{1}$

Affiliation:

${ }^{1}$ Departement of Systematic

Theology and Christian

Ethics, University of

Pretoria, South Africa

Correspondence to:

Danie Veldsman

email:

danie.veldsman@up.ac.za

Postal address:

Departement of Systematic

Theology and Christian

Ethics, University of

Pretoria, Lynwood Road,

Hatfield 0083, South Africa

Dates:

Received: 03 June 2010

Accepted: 08 July 2010

Published: 07 June 2011

How to cite this article:

Veldsman, D.P., 2011,

'Wat op dees (van)

aarde beteken die

einde van tradisionele

metafisiese taal oor

God? In gesprek met die

Nuwe-Testamentikus

Andries Gideon van Aarde

oor sy verstaan van ' $n$

postsekulêre spiritualiteit',

HTS Teologiese Studies/

Theological Studies 67(1),

Art. \#886, 6 pages. DOI:

10.4102/hts.v67i1.886
\end{abstract}

C 2011. The Authors. Licensee: OpenJournals Publishing. This work is licensed under the Creative Commons Attribution License.

\begin{abstract}
What does the end of traditional metaphysical language about God mean? In conversation with New Testament scholar Andries Gideon van Aarde on his understanding of a postsecular spirituality

South African New Testament scholar Van Aarde's explorative search for a new direction in theological reflection is explicated in this article with reference to his discussion of Peter Berger and Charles Taylor's contemporary contributions, which Van Aarde takes as vantage point to articulate the meaning of his 'courage to be a religious person today'. The articulation of his 'courage' to pursue a post-theistic understanding of a contemporary Christian religiosity (read: spirituality) that is non-fundamentalistic, non-populist and post-secular is discussed. At the same time, the basic tenets of his explorations are indicated, being constituted - negatively - by a de-centering of the power of institutional religion and, positively, by the enchantment of a Biblical hermeneutics that does not emphasise a proposition-like and moral code-like reading strategy. Finally, his 'new direction', which finds expression in the articulation of a 'spirituality of living faith', is scrutinised. It exposes the shortcomings in his (individualistic) exposition within the new correlation of modernisation and pluralism, causing it subsequently to bypass the necessary contemporary outcome in social embodiment.
\end{abstract}

\section{Inleiding}

'Charles Taylor helped me to articulate that which I have already been doing: having the courage to be a religious person today' (Van Aarde 2009:6).

Om met die Nuwe Testamentikus Andries van Aarde in hierdie feesbydrae ' $n$ akademiese gesprek oor een van sy resente publikasies, Theological Trends in our Postsecular Age (2009), aan te knoop is van (w)aarde omdat hy hom op ' $\mathrm{n}$ besondere wyse - in metaforiese taal gestel nie aan die 'vrou-van-Lot-sindroom ${ }^{\prime 1}$ skuldig wil maak nie, maar juis die eietydse postsekulêre leefwêreld teologies hier en nou in die oë wil kyk, en ook vorentoe wil kyk, en sy geloof daaruit wil verwoord. Vandaar die titel van hierdie bydrae: 'Wat op dees (van) aarde beteken die einde van tradisionele metafisiese taal oor God?'. Ek wil waarderend en ingeperk fokus op Van Aarde se uiteensetting van wat die 'waagmoed om vandag 'n religieuse persoon te wees' vir hom beteken. As uitgangspunt neem ek eerstens sy bespreking van die bydraes van Berger en Taylor. Daarna word sy verstaan van die Godsprobleem en die einde van postmetafisiese segswyses oor God weergegee. Die slotgedeelte behels ' $n$ kritiese bespreking van sy verwoording uit ' $n$ tweede naïwiteit van 'n lewende geloof in 'n postsekulêre wêreld.

\section{Van Aarde oor Berger en Taylor}

Vir Van Aarde (2009:4) is die taak van akademiese teologie 'to identify both dated and creative ideas, originating from the contemporary world, which can provide a new direction'. Van Aarde wil in sy teologiese arbeid by uitstek 'n nuwe rigting verken en juis die teendeel najaag van dít wat Habermas (2002:75-76) as volg stel: 'The collapse of metaphysics caused theologians to assimilate to the atheism of university life, and thus betray their tradition.' Daarom het Van Aarde sy uitgangspunt in die soeke na 'n 'nuwe rigting', wat, te midde van kontemporêre teologiese strominge, tussen gedateerde oortuiginge en kreatiewe idees onderskei, en wel soos dit by die Amerikaanse sosioloog Peter Berger (1929-) en die Kanadese filosoof Charles Taylor (1931-) aangetref word. In Berger se geval vind Van Aarde aansluiting by sy afwysende hantering van

1.Met 'vrou-van-Lot-sindroom' verwys ek speels na die Ou-Testamentiese beskrywing (Gen 19) van Lot se vrou wat in ' $n$ soutpilaar verander het toe sy teruggekyk het ten spyte van die opdrag om dit nie te doen nie. Hiermee verwys ek dus na die dikwels intense verlange om in ' $n$ religieuse konteks in die ontsluiting en verwoording van die betekenis van ons geloof blywend net agtertoe te wil kyk. 
burgerlike godsdienstigheid ['civil religion']; by Taylor weer is dit sy verwoording van ' $n$ postsekulêre spiritualiteit. Aan hierdie twee aansluitingsmomente moet ons kortliks aandag gee ten einde Van Aarde se eietydse 'waagmoed' beter te verstaan.

Met sy boek The heretical imperative (1979) het Berger sterk klem gelê op die winspunt wat sekularisasie meegebring het, naamlik die besef dat sekere aspekte van die Christendom herformuleer moet word indien dit behou wil word, terwyl ander verwerp sal moet word (vgl Van Aarde 2009:1-2). Vir Berger is een van die aspekte wat verwerp moet word die oortuiging dat die Christendom op onfeilbare, eksterne outoriteit berus. Juis dít verhoed ' $n$ ware ontmoeting met die Christelike boodskap. In hierdie opsig moet sekularisasie verwelkom word, aangesien dit Christelikheid van 'gekultiveerde religie', of dan burgerlike godsdienstigheid, stroop. Op grond van die insig dat religie 'n kontingente konstruk is, wys Taylor op sy beurt in sy $A$ secular age (2007) teen die agtergrond van eietydse (tydelike) populêre religieuse konstrukte ${ }^{2}$ daarop dat ons nie volledig op sekulêre perspektiewe moet staatmaak nie. ${ }^{3}$ Dít sal volgens hom die verlies van die kritieke funksie van, en verwondering ['enchantment'] in, ons kulturele lewens teweegbring. Hierdie verlies sal juis tot ontnugtering ['disenchantment'] lei wat hand aan hand gaan met die ondergang van persoonlike geloof, en dus ook van religie. Ook sal die sekulêre sonder die spirituele 'n onaanvaarbare skeiding en wig bring - nie alleen tussen religie en die natuurwetenskappe nie, maar ook tussen religie en die ander geesteswetenskappe. Hierdeur sal die voller verantwoording van menswees ten opsigte van die strewe na betekenis - vanselfsprekend dus ook na religieuse betekenis - erg gereduseer en kragteloos gelaat word in die hantering van eietydse vraagstukke (byvoorbeeld rassisme). Wat die Christendom betref, kan dit volgens Taylor wél volledig in voorkoms verander (lees: transformeer), maar steeds blywend as Christelik herken word, ten spyte van (lees: te danke aan!) die verlies van ekklesiologiese mag. Hierdie veranderde of getransformeerde spiritualiteit kom by wyse van verstek ['a kind of default mode'] na vore. ${ }^{4}$ Teenoor die vroeëre mitologiese wêreld, staan moderne mense in ' $n$ gesekulariseerde wêreld waarin hulle kan kies of hulle religieus wil wees al dan nie. Meer pertinent gestel: Die keuse om religieus te wees is deesdae ' $n$ keuse van vertroue wat die verlange na die Goddelike in die ervaring van 'leegheid' stil.

Vir die herformulering wat Berger bepleit, en vir 'n getransformeerde spiritualiteit soos wat Taylor dit

2.Verskillende outeurs beskryf hierdie populêre religieuse konstrukte uiteenlopend, onder andere met terme soos 'bricolage', 'patchwork', 'zap culture' en 'meander culture' (vgl Van Aarde 2009:2).

3.Sekulariteit word in hierdie konteks verstaan as'n wêreldbeskouing en lewenswyse wat leeg gestroop is van ontsag vir die Goddelike. Du Toit (2006:54) kwalifiseer dit as volg: "The term "secularisation" (Latin saeculum, lit.: generation, age) originally referred to the state confiscation of ecclesiastic property. In a religious context it relates to the erosion of religious traditions and an exodus from the churches. It relates to the erosion of religious traditions and an exodus from the churches. It may also connote theological developments which, in confrontation with tradition, revelation (bible). The common denominator is alienation, which lies at the root revelation (bible).
of secularization.

4.Taylor (in Van Aarde 2009:3) verduidelik dit as volg: '... The habitus of people and their ideas functions as a paradigm, a kind of default mode to which they return involuntarily until such time as that default mode has changed.' verwoord, voer Van Aarde (2009:2) aan dat die wyse waarop die Bybel gelees word juis 'n struikelblok kan wees. Dít spruit uit die mens se spontane geneigdheid om - ten einde vrees te besweer en sekerheid na te jaag - Bybelse tekste te kodifiseer (oftewel proposisioneel te fikseer), en só die tekste juis te stroop van 'n getuieniskarakter tot 'n lewende geloof (vgl Van Aarde 2009:2). Dit is niks anders nie as 'n gerasionaliseerde soeke na beheer en mag as troos om in 'n gesekulariseerde wêreld te oorleef. Vir Van Aarde (vgl 2009:4) is daar egter benewens hierdie struikelblok ook ' $n$ verdere grenslyn wat op problematiese wyse getrek word, naamlik dié tussen geïnstitusionaliseerde religie en openbare teologie. Hierdie grenslyn het volgens Van Aarde besondere implikasies vir ons verstaan van die Goddelike. Hy noem dit die 'Godsprobleem'.

\section{Die Godsprobleem (en die einde van tradisionele metafisiese taal oor God)}

Hierdie stelling van die 'Godsprobleem' word kernagtig vasgevang in die beskrywing van geïnstitusionaliseerde religie in die verwesterste eerste-kontinentale wêreld ['Westernised firstcontinental world'], wat van teïsme deurtrek is en deur dogmatiese fideïsme aangevuur word (Van Aarde 2009:4). In aansluiting by Habermas se verstaan van die hellenisering van die Christendom, wat volgens Habermas 'n onvanpaste simbiose tussen metafisika en spiritualiteit teweeggebring het, voer Van Aarde (2009:4) aan dat die eietydse 'populist meander culture' die onvanpastheid van 'n skeidslyn tussen hoofstroomen charismatiese kerklike groeperinge blootlê. Albei verteenwoordig geïnstitusionaliseerde religie. Die lyn moet eerder tussen geïnstitusionaliseerde religie en spiritualiteit op die markplein (soos films, literêre werke en die kunste) getrek word. Dit is die taak van die akademiese teoloog om hieroor te besin, aangesien dít, volgens Van Aarde, juis die noodsaaklike ontmoetingspunt met wetenskaplike teologie uitmaak. Op hierdie punt sê hy: 'Academic theology's task is to identify both dated ideas and creative ideas, originating from the contemporary world, which can provide a new direction' (Van Aarde 2009:4).

Vir Van Aarde is uitgediende idees (byvoorbeeld fundamentalistiese kreationisme, konfessionele fideïsme, kultuur-teologiese burgerlike religie, ensovoorts) teïsties georienteer, en is hý eerder op soek na 'n postteïstiese spiritualiteit. Dít word juis gevind by bogenoemde skeidslyn, waar wetenskaplike insigte (soos dié van die relatiwiteitsteorie, kwantumfisika en genetika) verreken word in ons Skrifbeskouing, wat meewerk tot die 'grammatika van religie' in samehang met die 'grammatika van die wetenskap'.${ }^{5}$ Hieruit volg dat ons moet erken dat ons tradisionele metafisiese taal oor God nie meer houbaar is nie, aangesien dit met wetenskaplike insigte bots. Vir Van Aarde

5.Van Aarde (2009:5) verduidelik sy punt as volg: 'Contemporary biblical religious language "translates" myths from a pre-modern world into myths from a scientific world. The gospel is not sold out to "facts" and "theories", however. It is always critical of the physical reality, including human culture.' 
(2009:5) vloei transendensie ('out there') en immanensie ('here') in ons kontemporêre wêreld ineen. Hy stel dit as volg: 'Our understanding today is that the metaphysical and the physical have merged' (Van Aarde 2009:5). Hierdie 'samevloeiende saamspel' verwoord Van Aarde (2009:5) hierna met betrekking tot enkele tradisionele dogmatiese loci, naamlik Christologie, pneumatologie, ekklesiologie en Skrifbeskouing. Hy voeg dit alles saam in sy twee-in-eenslotvraag: Beteken dit dan die einde van institusionele religie en van sy (Van Aarde se) verstaan van die moed om religieus te wees?

\section{Die moed om vandag vanuit ' $n$ tweede naïwiteit religieus te wees}

Vir Van Aarde (2009:6) impliseer ons postsekulêre konteks dat geïnstitusionaliseerde religie nie meer die status quo kan probeer handhaaf nie. Vir hom is die implikasie hiervan vir die kerk as instelling dat communio weer tot haar reg sal kom in wat hy, in aansluiting by Dingemans, 'n 'round table church' noem (Van Aarde 2009:6). In sy eie woorde: '... By its "de-instutionalisation" the church should again become the place where human beings encounter the divine by remembering Jesus within the context of sharing faith experiences' (Van Aarde 2009:6).

Vir Van Aarde is communio in die geloofsgemeenskap die grondslag van, en ontmoetingsplek met, God deur die antieke tekste, tradisies van die verlede, en ervaringe in die hede, met mense in die werklike werklikheid, ongeag verskille in oortuiging. Hiervandaan moet die geloofsgemeenskap krities en sorgvuldig tussen die kulturele immanente en dít wat transendent is, onderskei (alhoewel die twee volgens hom altyd gemeng is in ons lewens). Indien hierdie sorgvuldige onderskeid nie getref word nie, loop die geloofsgemeenskap gevaar om in 'slegte geloof' te verval (Berger noem dit 'bad faith as civil religion'; Taylor praat op sy beurt van eksklusiewe humanisme). Hierteenoor staan 'n lewende geloof in die teenwoordigheid van God, en as moreel verantwoordelike mense teenoor alle ander mense. Dit is dus nie die einde van religie nie - maar kán dit wel wees in 'n postsekulêre konteks indien 'religio' vanuit 'n eerste naïwiteit as bindend verstaan word, en bepaald die 'keeping in protective custody' veronderstel. In aansluiting by Ricoeur, wil Van Aarde egter 'religio' vanuit 'n tweede naïwiteit as 'terugkeer' ${ }^{6}$ verstaan, synde bepaald ' $n$ binding aan die verlede (herinnering) wat in die hede as't ware vir die eerste keer met ' $n$ nuwe betekenis herbeleef word. Hierdie nuwe betekenis - as inhoudelike samevatting van wat dit vir Van Aarde beteken om in waagmoed ' $n$ religieuse persoon te wees - word ten slotte as volg verwoord: 'Being religious is to de-secularise our world by living in the presence of God as a Spirit-filled person. Such transcendence in everydayness implies living in a (Christian) moral manner' (Van Aarde 2009:6).

6.In aansluiting by die lerse filosoof Richard Kearney, word hierdie 'terugkeer' in drie stappe beskryf, te wete dié van prefigurasie, konfigurasie en refigurasie (vgl Van Aarde 2009:6).
Hierdie verwoording deur Van Aarde van sy waagmoed om vanuit ' $n$ tweede naïwiteit in ' $n$ postsekulêre konteks 'n religieuse persoon te wees $^{7}$ verg vervolgens kritiese beskouing.

\section{Individualistiese verskraling en die verpas van sosiale lyflikheid}

Die golf van sekularisme (en daarmee saam die verwetenskapliking van die wêreld) wat hoofsaaklik oor die afgelope drie eeue sedert die Aufklärung oor die Europese kontinent gespoel het (maar ook in 'n mindere of meerdere mate in ander wêrelddele), het toe, teen vurige voorspellings in, nié die einde van die Christelike religie teweeggebring nie. ${ }^{8}$ Die veelbesproke 'mondigwording van die rede' het toe nié aan al die verwagtinge voldoen nie. In die woorde van die Sweedse skrywer Ola Sigurdson (2010):

If human reason no longer holds out any promise to be absolute in the sense that it would be able to transcend all conditions of language and history, there are no longer any absolute reasons to claim that the possibility of a religious existence ceases to be an option for serious, thinking human beings.

(Sigurdson 2010:179)

Veel eerder vind ons op verrassende wyse in die 21ste eeu die 'terugkeer' van religie. Peter Berger (1999:2) merk op dat die wêreld van vandag '... is as furiously religious as it ever was, and in some places more so than ever'. Ook Jonathan Benthall (2009:3) skryf in Time Magazine: 'In spite of science and secularism, religions are gaining strength ...'. Selfs in invloedryke filosofiese kringe word aangevoer dat 'religion has not at all exhausted its intellectual resources' (Sigurdson 2010:179). ${ }^{9}$ In dié verband is die opmerking van die Britse Marxis Terry Eagleton (2004:100) veral gepas: '... To speak of a post-religious age is to speak a good deal too hastily.' Eagleton (2009:167) voer hierdie opmerking insiggewend verder in sy Reason, Faith and Revolution wanneer hy sê, ongeag hoe ongeloofwaardig sekere van die religieuse waarheidsaansprake ook al mag wees, dit is steeds 'one of the most ambitious theoretical arenas left in an increasingly specialized world - one whose subject is nothing less than the nature and destiny of humanity itself, in relation to what it takes to be its transcendent source of life. ${ }^{10}$

Hierdie onuitputlike, verrassende terugkeer van religie word in baie eietydse publikasies verwoord wat nie alleen oor 'n breë spektrum (byvoorbeeld filosofies, psigologies,

\footnotetext{
7. Hierdie fomulering van Van Aarde herinner sterk aan die Duits-Amerikaanse teoloo Paul Tillich se boek met die titel Der Mut zum Sein (1953).

8.Sigurdson (2010:185) maak in hierdie verband dié insiggewende opmerking: 'Perhaps no part of the world is as surprised over the recent upsurge of religious movements across the globe as Europe. In Europe more than anywhere else, it has been taken for granted that modernity and progress more or less means the decreasing importance if not the eventual disappearance of religious faiths. In the grand old thesis of secularization, modernization is correlative to the decreasing importance of religion. Now the correlative is modernization and pluralism.

9. In die volgende gedeelte maak ek op my eie wyse dog met erkenning op verskillende punte gebruik van enkele insigte en samehange wat Sigurdson (2010) in sy baie goeie artikel oor sekularisme aantoon.

10.Sigurdson (2010:183) wys egter op Eagleton se belangrike kwalifikasie wanneer laasgenoemde sê dat alhoewel teologie op baie plekke in die wêreld steeds deel van die probleem is, dit 'nonetheless exhibits the capacity to foster the kind of van die probleem is, dit 'nonetheless exhibits the capacity to foster
critical reflection which might contribute to some of the answers'.
} 
sosiologies, selfs natuurwetenskaplik!) strek nie, maar ook in uiteenlopende temas (soos die natuurlikheid van religie; verwondering) en verskillende media (soos musiek en films) uiting vind, ${ }^{11}$ en boonop deur onder andere uitgesproke ateïste en agnostici (soos Richard Rorty, Terry Eagleton en Slavoj Zizek) ondersteun word.

Dít is die konteks waarin Van Aarde sy teologiese bydrae doelbewus plaas, en dít is dan ook die konteks waarin dit beoordeel moet word. Sy waagmoed is, na my teologiese oordeel, navolgbaar en prysenswaardig. Die navolgbaarheid daarvan is daarin opgesluit dat hy 'n Christelike weg (her) verwoord wat moedig in 'n eietydse postsekulêre konteks ingeslaan kan word. Sy beklemtoning van 'n tweede naïwiteit, van 'n 'terugkeer' en communio, maak 'n besondere deel uit van sy verwoording van die nuwe teologiese koers wat hy met onderskeiding wil inslaan. Hy is tereg afwysend teenoor die religieuse vergestaltinge van die gerasionaliseerde, misloopte soeke na beheer en mag in geïnstitusionaliseerde religie. Benewens navolgbaar, is sy ingeslane koers ook prysenswaardig - op 'n positiewe én negatiewe wyse. Enersyds is dit positief prysenswaardig omdat dit meer as die moeite werd is om deeglik daarvan kennis te neem en met Van Aarde in gesprek te tree, want dit gaan oor die integriteit van die Christelike boodskap self en 'n lewende geloof hier en nou. Andersyds is daar - negatief gesproke - 'n 'prysgee' (in die sin van 'n waardevolle dimensie wat verlore gaan of nie in spel kom nie) van lyflikheid, en dan spesifiek sosiale lyflikheid. Kortom: Deur 'n individualistiese verskraling verpas Van Aarde ons onvermydelike sosiale lyflikheid - en dít kan nie, want dit is na my oordeel een van die samestellende dele van die individu se lewende (lyflike) geloof. Hierop wil ek verduidelikend fokus, met Van Aarde se pleidooi vir die erns maak met eietydse wetenskaplike ontwikkelinge as invalshoek. Eerstens kom sy klem op die belang van natuurwetenskaplike insigte aan die orde in ' $n$ kritiese bespreking van sy beklemtoning van die ontmoetingslyn. Tweedens reageer ek positief op sy kritiek op die kerk se gerasionaliseerde soeke na beheer en mag, maar stel ek wél vrae ten opsigte van beliggaamde rasionaliteit, wat die plek van voormelde soeke na beheer en mag moet inneem.

Saam met Van Aarde (en baie ander, soos Du Toit 2006:66ff; Vroom 2008:576ff om maar net twee voorbeelde te noem) wil ek eerstens hartstogtelik pleit dat grondig erns gemaak word met eietydse wetenskaplike insigte. Ons kan nie langer onsin - by wyse van wetenskaplike spreke - soos 'God het ons lief op hierdie mooi plat aarde van ons wat in sewe dae geskep

11.Om maar net enkele meer resente voorbeelde van boeke te noem: Supernatural as Natural: A Bio-cultural approach to religion (2010) deur Michael Winkelman en John Baker; God is back: How the Global Revival of Faith is Changing the World (2009) deur John Micklethwait en Adrian Wooldridge; Postsecularism: The Hidden Challenge to Extremism (2009) deur Mike King; The Plot to Kill God (2008) deur Paul Froese; Reason, Faith and Revolution: Reflections on the God Debate (2009) deur Terry Eagleton; The Palm at the end of the Mind (2009) deur Michae Jackson; Do we need religion?: On the experience of selftranscendence (2008) deur Jackson; Do we need religion?: On the experience of selftranscendence (2008) deu Hans Joas (uit Duits vertaal). Twee ouer werke wat ook steeds in hierdie verband belangrik is, is The Fragile Absolute: Or, Why is the Christian Legacy Worth Fighting For? (2000) deur Slavoj Zizek, en die versamelwerk The Future of Religion (2005) waarvan Santiago Zabal die redakteur is. In Suid-Afrika het die Navorsingsinstituut Secular Spirituality as a Contextual Critique of Religion gepubliseer is. is' duld nie. Maak dit nie juis die eerste gedeelte van hierdie geloofsbelydenis ('God het ons lief') ongeloofwaardig as die tweede gedeelte doodgewoon wetenskaplike onsin is nie? Ek meen so. Maar meer nog: Ook die inkonsekwente kerklike kieskeurigheid van teologiese standpunte oor eietydse wetenskaplike insigte verg dringend aandag. In die een geval word die biologiese argument moreel betrek (God het ons biologies só as man en vrou gemaak) om homoseksualiteit te veroordeel, maar terselfdertyd word die 'biologiese wetenskappe' nie in sy geheel geken nie (byvoorbeeld genetiese insigte), en selfs verder geïgnoreer wat die skeppingsvraag na die mens (byvoorbeeld die standpunte oor evolusie) betref. Hierdie ondersoekende implikasies en die dringendheid van Van Aarde se standpunt kan ek met opgewondenheid ondersteun. Dan steek Van Aarde egter na my mening - as ek hom reg verstaan - te gemaklik dít wat hy die wetenskaplike lyn van ontmoeting noem, oor. In die eerste plek meen ek dat dit nie 'n lyn genoem kan word nie, maar eerder 'n ruimte, en inderdaad 'n opwindende (epistemies-hermeneutiese) ruimte. Dit is weliswaar ' $n$ opwindende ruimte, maar tog onoorsigtelik en onuitputlik dig aan intensies (én dimensies) - so dig dat vele standpunte (of perspektiewe) in hierdie ruimte erg toegewasem daar uitsien. Dit is 'n ruimte wat nogtans op allerlei uiteenlopende wyses (selfs weersprekende wyses) en toenemend druk besoek word deur besoekers wat 'n veelgestaltige, breë sinsoekende en sinbelewende simfonie dog ook kakofonie daaruit te voorskyn bring. Enkele konkrete voorbeelde van invloedryke publikasies in hierdie verband sluit in Richard Dawkins se The God Delusion (2006) en Alister McGrath se kritiese reaksie daarop in sy The Dawkins Delusion (2007); McGrath se The Fine-Tuned Universe: The Quest for God in Science and Theology (2009) en Science and Religion (2010); Philip Clayton en Paul Davies (2006) se The Re-emergence of emergence: The emergentist hypothesis from Science to Religion; Clayton se Mind and emergence: From Quantum to Consciousness (2006), en Davies se The Goldilocks Enigma: Why is the Universe just right for life (2006).

As akademiese teoloë na geloofwaardigheid en integriteit soek, sal hulle erns moet maak met die oënskynlike eenstemmigheid van die natuurwetenskappe wat inderdaad geen eenstemmigheid is nie. My hieropvolgende opmerkings oor dienatuurwetenskappe is nie bedoel om dieverbysterende en fassinerende bydrae van die natuurwetenskappe enigsins te minimaliseer of te degradeer nie, maar om dit hermeneuties te kwalifiseer. Benewens ingrypende (metodologiese) verskille, is daar ook die fundamentele verskil tussen groot en klein; tussen relatiwiteitsteorie en kwantumfisika. In hierdie wetenskaplike ruimtes is enige wetenskaplike ondersoek veelduidig - en moet dít erken word. Die ontsluiting van beskouinge van ons 'groot' wêreld (kosmologie) is kwalik, of nie sonder meer nie, versoenbaar met die ontsluiting van beskouinge van die 'klein' wêreld van kwantumfisika. Dit is tot nog toe - in wetenskapsfilosofiese taal - onversoenbare paradigmas: Vandaar die natuurwetenskaplike versugting na ' $\mathrm{n}$ 'Grand Unifying Theory'. Teoreties het dit nog nie geslaag nie. Terselfdertyd word gewys op die ineenstorting van die sogenaamde 'Reductionist Program' (vgl Clayton 2005:344ff). 
Nie alleen is onversoenbaarheid hier ' $n$ basiese probleem nie, maar ook onoorsigtelikheid. Laat ek verduidelik: Ter wille van hierdie argument stel ek my die natuurwetenskappe voor as 'n moderne, hoogs gesofistikeerde Airbus-vliegtuig, waarin niemand meer die geheel kan oorsien nie, en nog minder kan bestuur. Tog weet en sien ons dat dit vreeslik goed werk, en sonder om ons daaroor te bekommer dat niemand die geheel kan oorsien of hanteer nie, maak ons (gerus?) as passasiers daarvan gebruik. Weliswaar kan die loods die verantwoordelikheid neem om die Airbus veilig op koers te hou en te laat land, maar as daar fout gaan met die elektronika, of indien 'n strukturele probleem opduik, kan die loods - ten spyte van sy of haar besorgdheid oor die passasiers - weinig doen. Ander - wat weer op hulle beurt ook nie die geheel kan oorsien nie - word gevra om hand by te sit. Van werklike onversoenbaarheid en onoorsigtelikheid in die ontmoeting van wetenskap en teologiese nadenke - en dus ook van integrasie - is daar nie sprake by Van Aarde se ontmoetingslyn nie. Nog minder kan gemaklik van 'n sogenaamde - soos Van Aarde dit inderdaad noem - 'grammatika van die wetenskap' gepraat word. Hierdie ruimte is baie digter, veeldimensioneel en veelkantig ( $\mathrm{vgl}$ Clayton 2005:342ff; Deane-Drummond 2005:357ff), sodat verskillende 'grammatikas' ter sprake is. Boonop vind ons in hierdie 'fisiese' ruimte van natuurwetenskaplike nadenke al hoe meer ander vreemdhede. So is daar byvoorbeeld fisici wat hulle 'skaamteloos' aan metafisiese spekulasie skuldig maak (vgl Paul Davies) - en dít terwyl enkele teoloë al hoe meer terughoudend is oor tradisionele metafisiese taalgebruik. Hiermee my vraag aan Van Aarde: Beteken dit dus dat die bevraagtekening - tereg - van tradisionele metafisiese taal, metafisiese taal as sodanig ophef? Of vra dit net indringend na nuwe (metafisiese) verwoording?

Ten nouste hiermee saam gaan ' $\mathrm{n}$ diepgaande besinning oor die aard van die menslike bewussyn en soeke na betekenis wat veel meer inhou as dít wat wetenskaplik verklaar kan word. Meer as 20 jaar gelede het die Britse kosmoloog Harrison (1919-2007) voormelde al baie eenvoudig dog treffend verwoord:

The world we live in with our thoughts, passions, delights, and whatever stirs the mortal frame must surely take on a deeper meaning. Songs are more than longitudinal sound vibrations, sunsets more than transverse electromagnetic oscillations, inspirations more than the discharge of neurons, all touched with a mystery that deepens the more we contemplate and seek to understand.

(Harrison 1985:273)

Saam met hierdie soeke na 'dieper betekenis' en die omvattende besinning oor menslike bewussyn, is daar die meer toegespitse navorsing oor die (analogiese) verband tussen bewussyn en liggaamlikheid. Hiervoor het die Britse filosoof Colin McGinn (1950-) al amper twee dekades gelede as volg gepleit:

We need to cultivate a vision of reality (a metaphysics) that makes it [reality] truly independent of our given cognitive powers, a conception that includes these powers as a proper part. It is just that, in the case of the mind-body problem, the bit of reality that systematically eludes our cognitive grasp is an aspect of our own nature. Indeed, it is an aspect that makes it possible for us to have minds at all and to think about how they are related to our bodies. This particular transcendent tract of reality happens to lie within our own heads. A deep fact about our own nature as a form of embodied consciousness is thus necessarily hidden from us.

(McGinn 1994:113)

Hierdie bepaalde faset van 'menslike transendensie' in (analogiese) relasie tot ons verstaan van transendensie in die algemeen staan na my oordeel (gegewe die nuwe opbloei in natuurwetenskaplike kringe) in haar kinderskoene - en is dalk nie so plat op die aarde as wat ons dalk wil voorgee nie (vgl Veldsman 2010). Waaroor die huidige transendensiediskoers presies gaan, is ook nie heeltemal so maklik vas te pen nie:

After all, for all its authority and prestige, the word 'transcendent' is a relative term: It depends on what is being transcended, and there is a long list of candidates - the subject, the self, the sensible world, beings, even Beings itself - and so there is nothing to stop us from wondering whether itself is to be added to the list as still one more thing to be transcended.

(Caputo \& Scanlon 2007:2)

Om dus tradisionele metafisiese taal af te maak; daarmee sonder meer metafisiese taal in totaliteit te skrap; vervolgens ons verstaan van 'transendensie' (wat dit ook al beteken!) tot slegs die etiese of morele te reduseer, en aan te voer dat dit ál 'transendensie' is wat oorbly, is na my oordeel eenvoudig te haastig en te min: te haastig, want dit is (nog) nie alte duidelik waarmee presies ons hier te make het nie, en te min, want is dit nie om maar net 'meer' van dieselfde 'hier' te poneer nie? Lê daar nie, soos reeds hier bo genoem, in die menslike bewussyn, daar waar die 'oorgang' van fisies-chemiese prosesse na bewussyn op ' $n$ onverklaarbare, misterieuse wyse plaasvind, ' $n$ (analogiese) spoor van transendensie en dus van die metafisiese nie ${ }^{12}$ Benewens die vrae aan Van Aarde oor die metafisiese, is daar egter ook nog vrae oor tyd. Die voorafgaande herbenoeming van die ontmoetingsplek van wetenskap en teologie - nie as lyn nie, maar as ruimte - bring tweedens onvermydelik die tyd-dimensie van menswees ter sprake. Historisiteit móét verreken word. Dít (en daarmee saam die ruimte-tyd-samehang) is egter 'n dimensie wat Van Aarde persoonlik inperk, met negatiewe, verskralendegevolge. Alhoewelhy tereg diegerasionaliseerde (ekklesiologiese) soeke na beheer en mag kritiseer, maak hy nie nuwe plek vir ' $n$ beliggaamde rasionaliteit wat die plek daarvan moet inneem nie. Vollediger gestel: Ek self, as

12. Hierdie punt moet verduidelik word. Ek wil geensins beweer dat hierdie spoor van transendensie wat in die mens gevind en ondersoek kan word, aan ons soekende transendente ondersoek as 'opeenvolgende beweginge' só verduidelik ten einde juis ook die ondersoek as 'opeenvolgende beweginge' so verduidelik ten einde juis ook die
verskil te beklemtoon: 'Transcendence - what on earth are we talking about, verskil te beklemtoon: "Transcendence - what on earth are we talking about,
is - as first movement (the motivation thus for the "first movement" is simply is - as first movement (the motivation thus for the "first movement" is simply
taking seriously the biological roots of rationality and the implications thereo of an interdisciplinary conversation between theology-sciences) to take cognizance of the best scientific theories we have of the relationship of our mind / (self) consciousness to our bodies in order to identify clues / elements for the structuring of a theological form / template for making sense of transcendence. Subsequently - as second movement (the motivation thus for the "second movement" lies in the pursued aim of being self-critical, of revision and credibility) - to explore, to undertake revision of our transcendent-rhetoric and to articulate the theological implications of these findings. And as ongoing movement, to theologically discern implications of these findings. And as ongoing movement, to theologically discern the ways in which God's relation to the universe, God's transcendence also differs from the relation of our mental properties to our brain and bodies. Without doub (!) the reflection on transcendence will ultimately move beyond the realm of mpirical knowledge and control (it has to!), will ultimately include faith and trust since - after all - beliefs about transcendence, although re-imagined in a credible interdisciplinary manner, are ultimately not "checkable" by any scientific means given its (that is, faith's) invitational character' (Veldsman 2010:8). 
beliggaamde, bestaan ook uit my sosiale lyflikheid. Ek meen Van Aarde verreken dit nie konsekwent nie. Ek sluit hier aan by Sigurdson (2010:191) wanneer hy aanvoer:

... Any religious community is inevitably political, insofar as it is bound, as a collective, to have impact on the practices and beliefs of its adherents but also on the people belonging to other communities (religious or not) with which the religious community interacts.

(Sigurdson 2010:191)

Van Aarde beklemtoon en herformuleer die ekklesiologiese besonderheid van communio, van 'n 'round table church', en van 'ontmoeting' met 'ander'. Hy voeg by dat dit veral as 'lewende geloof in die teenwoordigheid van God en as moreel verantwoordelike mense teenoor alle ander mense' gestalte moet vind. Hierdie communio, hierdie persoonlike oproep, word egter eksklusief en individualisties verdag wanneer die konkrete 'ander' van die Suid-Afrikaanse konteks, en dus die groter Afrika-konteks, opvallend in hierdie ('ontmoetingsvolle') uiteensetting ontbreek. Het ons nie almal saam, in besinning oor sekulariteit en die herformulering van die betekenis van communio, 'n plek (lees: stem) aan hierdie ronde tafel nie (vgl Du Toit 2006:61ff; Prozesky 2006:127; Mndende 2006:153ff)? In hermeneutiese kringe word onder andere vandag beklemtoon dat die persoonlike nooit die 'politieke' (as die inrigting van ons lewensruimte) uitsluit nie, maar juis impliseer. Ek meen verder dat Sigurdson (2010) se beskouing van ons postsekulêre konteks, naamlik dat dit gekenmerk word deur 'n verskuiwing vanaf ' $n$ vroeëre korrelasie, synde moderniteit:religiositeit, na ' $n$ nuwe korrelasie, synde moderniteit:pluralisme, in hierdie verband insiggewend is. Waar kom hierdie pluralisme dan in Van Aarde se uiteensetting ter sprake? Enersyds in sy betekenisvolle klem op communio, maar andersyds in die uitsluiting van die konkrete stemme van die ander, wat gevolglik die persoonlike op individualistiese wyse verskraal, met 'n miskenning van die eietydse (sosiale) plurale konteks waaruit die 'ons' gesamentlik bestaan. Meer nog: Het die communio, wat ook uit sosiale lyflikheid bestaan, dan nie juis in so ' $n$ konteks van die einde van geïnstitusionaliseerde religie opnuut ' $n$ besondere (bemagtigde) kritieke funksie (en plek) in die samelewing wat eietydse (politieke) vraagstukke (soos klassisme, rassisme, die ekologiese krisis, en etiese kwessies soos homoseksualiteit) betref nie? Ek meen dat, ten spyte van die nuut geformuleerde religieuse inhoude in ' $n$ postsekulêre konteks, hierdie individualistiese verskraling sonder enige ekklesiologiese lyflikheid (in teologiese taal: liggaam van Christus) die Christelike boodskap gevaar laat loop om tot 'n (lokale) spookstem te muteer, en haar sosiaal transformerende potensiaal te verpas.

Ek sluit af. Van Aarde se kritieke 'waagmoed' om sy 'terugkeer' na 'n lewende Christelike geloof vanuit ' $\mathrm{n}$ tweede naïwiteit in 'n postsekulêre konteks te verwoord, ontketen na my oordeel 'n opwindende en uitnodigende spektrum teologiese insigte en impulse, wat voortbeurend ernstig opgeneem moet word. Ek noem dit doelbewus 'voortbeurend', want enersyds stel dit die ondersoeker wat die waagmoed aan die dag lê persoonlik bloot, en andersyds beitel dit aan ons gesamentlike teologiese integriteit van hier en nou, sodat ons vorentoe kan beweeg.

\section{Literatuurverwysings}

Benthall, J., 2009, 'Beyond Belief', TLS, 11 December, p. 3.

Berger, P.L., 1999, 'The Desecularization of the World: A Global Overview', in P.L. Berger (ed.), The Desecularization of the World: Resurgent Religion and World Politics, pp. 1-18, Eerdmans, Grand Rapids.

Caputo, J.D. \& Scanlon, M. (eds.), 2007, Transcendence and Beyond: A postmodern inquiry, Indiana University Press, Bloomington.

Clayton, P., 2005, 'Theology and the Physical Sciences', in D. Ford (ed.), The Modern Theologians, pp. 342-356, Blackwell, Oxford.

Deane-Drummond, C., 2005, 'Theology and the Biological Sciences', in D. Ford (ed.) The Modern Theologians, pp. 357-369, Blackwell, Oxford.

Du Toit, C. (ed.), 2006, 'Secular spirituality versus secular dualism: Towards postsecular holism as model for a natural theology', in C. du Toit \& C. Mayson (eds.), Secular Spirituality as a Contextual Critique of Religion, pp. 49-73, University of South Africa, Pretoria.

Eagleton, T., 2004, After Theory, Penguin Books, London.

Eagleton, T., 2009, Reason, Faith, and Revolution: Reflections on the God Debate, Yale University Press, London.

Habermas, J., 2002, Religion and rationality: Essays on reason, God and modernity, ed. E. Mendieta, Polity Press, Cambridge.

Harrison, E., 1985, Masks of the Universe, Macmillan, New York.

McGinn, C., 1994, 'Can we solve the mind-body problem', in R. Warner \& T. Szubka (eds.), The mind-body problem: A guide to the current debate, n.p., Blackwell, Cambridge.

Mndende, N., 2006, 'Spiritual reality in South Africa', in C. du Toit \& C. Mayson (eds.), Secular Spirituality as a Contextual Critique of Religion, pp. 153-174, University of South Africa, Pretoria.

Prozesky, M., 2006, 'Ethics, spirituality and the secular', in C. du Toit \& C. Mayson (eds.), Secular Spirituality as a Contextual Critique of Religion, pp. 127-138, University of South Africa, Pretoria.

Sigurdson, O., 2010, 'Beyond secularism? Towards a post-secular Political Theology', Modern Theology 26(2), 177-196. doi: 10.1111/j.1468-0025.2009.01593.x

Van Aarde, A.G., 2009, 'Theological Trends in our Postsecular Age', Verbum et Ecclesia 30(3), 1-8.

Veldsman, D.P., 2010, 'Transcendence: What on earth are we talking about?', paper presented at the conference Faith, Religion and the Public University, Faculty of Theology, University of Orange Free State, Bloemfontein, 23-24 March.

Vroom, H., 2008, 'Een theologische faculteit als huis van vele woningen: Over de institusionaliseing van de theologie in de pluralistische, seculiere samenleving', Verbum et Ecclesia 29(2), 562-585. 